\title{
Mammalian target of rapamycin signaling and ubiquitin proteasome-related gene expression in 3 different skeletal muscles of colostrum- versus formula-fed calves
}

\author{
H. Sadri, ${ }^{*} \dagger^{1}$ J. Steinhoff-Wagner, $\ddagger^{1,2}$ Harald M. Hammon, $\ddagger$ R. M. Bruckmaier,§ S. Görs, $\ddagger$ and H. Sauerwein ${ }^{* 3}$ \\ ${ }^{*}$ Institute of Animal Science, Physiology and Hygiene Unit, University of Bonn, 53111 Bonn, Germany \\ †Department of Clinical Science, Faculty of Veterinary Medicine, University of Tabriz, 5166616471 Tabriz, Iran \\ †lnstitute of Nutritional Physiology "Oskar Kellner," Leibniz Institute for Farm Animal Biology, 18196 Dummerstorf, Germany \\ §Veterinary Physiology, Vetsuisse Faculty, University of Bern, CH-3012 Bern, Switzerland
}

\begin{abstract}
The rates of protein turnover are higher during the neonatal period than at any other time in postnatal life. The mammalian target of rapamycin (mTOR) and the ubiquitin-proteasome system are key pathways regulating cellular protein turnover. The objectives of this study were (1) to elucidate the effect of feeding colostrum versus milk-based formula on the mRNA abundance of key components of the mTOR pathway and of the ubiquitin-proteasome system in skeletal muscle of neonatal calves and (2) to compare different muscles. German Holstein calves were fed either colostrum $(\mathrm{COL} ; \mathrm{n}=7)$ or milk-based formula (FOR; $\mathrm{n}=7)$ up to $4 \mathrm{~d}$ of life. The nutrient content in formula and colostrum was similar, but formula had lower concentrations of free branched-chain AA (BCAA) and free total AA, insulin, and insulin-like growth factor (IGF)-I than colostrum. Blood samples were taken from d 1 to 4 before morning feeding and before and $2 \mathrm{~h}$ after the last feeding on d 4. Muscle samples from M. longissimus dorsi (MLD), M. semitendinosus (MST), and M. masseter (MM) were collected after slaughter on d 4 at $2 \mathrm{~h}$ after feeding. The preprandial concentrations of free total AA and BCAA, insulin, and IGF-I in plasma changed over time but did not differ between groups. Plasma free total AA and BCAA concentrations decreased in COL, whereas they increased in FOR after feeding, resulting in higher postprandial plasma total AA and BCAA concentrations in FOR than in COL. Plasma insulin concentrations increased after feeding in both groups but were higher in COL than in FOR. Plasma IGF-I concentrations decreased in COL, whereas they remained unchanged in FOR after feeding. The mRNA
\end{abstract}

\footnotetext{
Received March 10, 2017.

Accepted May 17, 2017.

${ }^{1}$ These authors contributed equally.

${ }^{2}$ Present address: Institute of Animal Science, Preventive Health Unit, University of Bonn, 53111 Bonn, Germany.

${ }^{3}$ Corresponding author: sauerwein@uni-bonn.de
}

abundance of $m$ TOR and ribosomal protein S6 kinase 1 (S6K1) in 3 different skeletal muscles was greater in COL than in FOR, whereas that of eukaryotic translation initiation factor $4 \mathrm{E}$ binding protein 1 ( $4 E B P 1$ ) was unaffected by diet. The mRNA abundance of ubiquitin activating enzyme (UBA1) and ubiquitin conjugating enzyme 1 (UBE2G1) enzymes was not affected by diet, whereas that of ubiquitin conjugating enzyme 2 (UBE2G2) was greater (MLD) or tended to be greater (MM) in COL than in FOR. The mRNA abundance of atrogin-1 in MLD and MST was lower in COL than in FOR, whereas that of muscle ring finger protein-1 (MuRF1) was greater (MST) or tended to be greater (MLD). The abundance of MuRF1 mRNA was highest in MST, followed by MLD, and was lowest in MM. The results indicate that colostrum feeding may stimulate protein turnover that may result in a high rate of protein deposition in a muscle type-specific manner. Such effects seem to be mediated by the postprandial increase in plasma insulin.

Key words: mammalian target of rapamycin, ubiquitin-proteasome system, muscle, neonatal calf

\section{INTRODUCTION}

The transition from intra- to extrauterine life is associated with dramatic changes in nutrient supply. The constant supply of glucose and AA via the placenta is replaced by an inconstant supply of lactose, fat, and protein and AA via colostrum and milk in the suckling newborn (Ferre et al., 1986; Girard, 1990; Blum, 2006). Feeding colostrum to neonatal calves after birth is considered the most important management measure in postnatal nutrition. Colostrum is a valuable source of IgG and nutrients and contains many biologically active compounds, such as insulin and growth factors that are crucial for health and postnatal development of neonatal calves (Blum and Hammon, 2000; Blum, 2006; Penchev Georgiev, 2008; Ontsouka et al., 2016). Results reported about the metabolic and endocrine 
changes in particular of glucose metabolism as part of this experiment (Steinhoff-Wagner et al., 2011, 2014) demonstrated an improvement in the glucose status of colostrum-fed calves over formula-fed calves, mainly due to enhanced oral glucose absorption. In addition, the metabolic and endocrine changes, including elevated plasma urea concentrations, pointed to greater AA degradation in formula-fed calves than in colostrum-fed calves, probably to provide substrates for gluconeogenesis and to compensate for the lower intestinal absorptive capacity for glucose (Hammon and Blum, 1999; Rauprich et al., 2000; Hammon et al., 2003).

The neonatal period is characterized by the highest rates of protein turnover that support rapid rates of protein deposition (Davis et al., 1989). Protein turnover - the balance between protein synthesis and protein degradation - is controlled via several pathways whereby the mammalian target of rapamycin (mTOR) and ubiquitin-proteasome system (UPS) are regarded as the major regulators of protein synthesis and of the proteolytic pathway in skeletal muscle, respectively (Inoki and Guan, 2006; Nandi et al., 2006; David et al., 2010). Insulin and AA are recognized as key factors in the regulation of protein synthesis in muscle (Davis et al., 2010), and the response of skeletal muscle to these anabolic signals was reported to be dependent on muscle fiber type in neonatal pigs (Gazzaneo et al., 2011; Columbus et al., 2015).

Few studies have investigated protein anabolism in response to various combinations of formula, mature milk, or colostrum either in the gastrointestinal tract or in peripheral tissues in neonatal pigs (Burrin et al., 1995, 1997; Fiorotto et al., 2000). Furthermore, the stimulatory effects observed were attributed to nonnutritive (Fiorotto et al., 2000) or nutrient-dependent factors present in colostrum that are associated with rapid secretion of insulin (Burrin et al., 1995, 1997). However, to our knowledge, the question of whether feeding colostrum or formula may affect the regulation of specific signaling components in skeletal muscle related to protein synthesis and degradation in newborn calves has not been addressed. In the current study, we tested the hypothesis that the expression of mTOR signaling and UPS-related genes in skeletal muscle of neonatal calves is divergently affected by colostrum versus milk-based formula feeding and is related to the circulating concentrations of insulin and AA.

\section{MATERIALS AND METHODS}

\section{Animals, Treatments, and Experimental Design}

This experiment was conducted at the Research Station of the University of Rostock (Rostock, Germany).
Procedures for this study were in accordance with animal care guidelines and were approved by the relevant authorities of the State Mecklenburg-Vorpommern, Germany (LALLF M-V/TSD/7221.3-1.1-014/07). The animals in the present study were from a trial aiming to investigate the effect of colostrum feeding on glucose metabolism; more details about these aspects were provided in previous publications (SteinhoffWagner et al., 2011, 2014). Briefly, 14 newborn female Holstein calves $(\mathrm{BW}=45.9 \pm 1.0 \mathrm{~kg}$; mean $\pm \mathrm{SE})$ were studied in a completely randomized design. The calves were separated from their dams and transferred to single boxes bedded with clean straw until $4 \mathrm{~d}$ of age. The calves were randomly assigned to 2 groups, a colostrum (COL) group and a formula (FOR) group, each consisting of 7 animals. Calves were bottle fed either pooled colostrum obtained from d 1,2, and 3 postpartum or milk-based formula (Bergophor Futtermittelfabrik GmbH, Kulmbach, Germany) in which the contents of macronutrients were comparable with those of the respective colostrums on the first $3 \mathrm{~d}$ of life. On d 4, calves received either colostrum of d 3 (COL group) or formula of d 3 (FOR group). Calves received colostrum and formula at $8 \%$ of BW on d 1, $10 \%$ of BW from d 2 twice daily at 0800 and $1600 \mathrm{~h}$, and only a single portion ( $5 \%$ of $\mathrm{BW}$ ) at $0800 \mathrm{~h}$ on $\mathrm{d} 4$. Calves received their first meal at $4.4 \pm 0.6 \mathrm{~h}$ after birth. The composition of colostrum and formula fed to the calves is given in Supplemental Table 1 in Steinhoff-Wagner et al. (2011).

\section{Blood and Tissue Sampling}

Blood samples were taken from a jugular vein after birth, before first feeding of colostrum (d 1), from d 2 until $\mathrm{d} 4$ before the morning feeding. In addition, blood samples were taken $2 \mathrm{~h}$ after the last feeding on $\mathrm{d} 4$. Tubes containing $\mathrm{K}_{3}$ EDTA (1.8 g/L of blood) for analysis of insulin and IGF-I and Li-heparin (14-15 kIU/L of blood) for analysis of AA and dipeptide concentrations were placed on ice immediately after collection and centrifuged at $1,500 \times g$ at $4^{\circ} \mathrm{C}$ for $20 \mathrm{~min}$. The plasma was obtained and frozen $\left(-20^{\circ} \mathrm{C}\right)$ until analyses.

Calves were stunned by bolt shot and exsanguinated on d 4 of life $2 \mathrm{~h}$ postfeeding. Three different skeletal muscles were dissected from connecting tissue immediately, rinsed with ice-cold saline solution $(0.9 \% \mathrm{NaCl})$, snap frozen in liquid nitrogen, and stored ultradeep frozen until analysis. Sampled muscle types were chosen according to their fiber type composition: M. longissimus dorsi (MLD) and M. semitendinosus (MST) for predominantly white fast-twitch glycolytic fibers and M. masseter (MM) for red slow-twitch oxidative fibers. Tissue sample size was too small to perform analytical 
procedures other than determination of mRNA abundance.

\section{RNA Extraction and Quantitative Real-Time Reverse-Transcription PCR}

Total RNA was extracted from the muscle homogenates using Trizol (Invitrogen, Karlsruhe, Germany) according to the manufacturer's instructions. The extracted RNA was purified using Qiagen mini kit protocol (RNeasy Mini Kit, Qiagen, Hilden, Germany), including the on-column DNase I treatment to remove residual DNA contamination. Purity and concentration of the RNA were determined by measuring the absorbance at 260 and $280 \mathrm{~nm}$ using a Nanodrop 1000 (peQLab Biotechnology, Erlangen, Germany). Quality of the RNA was assessed using ethidium bromide denaturing RNA electrophoresis and rechecked in selected samples using a 2100 Bioanalyzer and RNA 6000 Nano Kit system (Agilent, Santa Clara, CA) according to the manufacturer's protocol to determine RNA integrity number $(\mathrm{RIN}=7.63 \pm 0.17)$. Reverse transcription was performed with $250 \mathrm{ng}$ of total $\mathrm{RNA} / 20-\mu \mathrm{L}$ reaction using $200 \mathrm{U}$ of Revert Aid reverse transcriptase, $500 \mu M$ of each deoxynucleotide triphosphate, and 20 $\mathrm{U}$ of RiboLock ribonuclease inhibitor (Fermentas, St. Leon-Rot, Germany) with 200 pmol of random hexamer primers (Sigma-Aldrich, St. Louis, MO) for 10 min at $27^{\circ} \mathrm{C}, 60 \mathrm{~min}$ at $42^{\circ} \mathrm{C}$, and $1 \mathrm{~min}$ at $99^{\circ} \mathrm{C}$. Each run included a no-template control and a no-reversetranscriptase control. The reverse transcription was performed in duplicate for each sample.

Analysis by quantitative real-time reverse-transcription PCR (qPCR) was performed in an Mx3000P cycler (Stratagene, Amsterdam, the Netherlands, and Agilent) in accordance with minimum information for publication of quantitative real-time PCR experiments (MIQE) guidelines (Bustin et al., 2009). The sample maximization method was used (i.e., different genes were measured on different plates). The characteristics of the primers and the real-time PCR conditions are given in Table 1 . The reaction was performed in triplicate in a total volume of $10 \mu \mathrm{L}$ comprising $2 \mu \mathrm{L}$ of cDNA (diluted 1:4) as template, $1 \mu \mathrm{L}$ of the assayspecific primer mix, $5 \mu \mathrm{L}$ of SYBR Green JumpStart Taq Readymix (Sigma-Aldrich), and $2 \mu \mathrm{L}$ of water. A negative template control for quantitative PCR as well as a negative template control and no reverse transcriptase control of cDNA were included in each run. For each PCR, a standard curve was generated using serial dilutions of cDNA to calculate efficiency-corrected relative quantities of the targets (run-specific target amplification efficiency).
To determine the most stably expressed genes across treatments and muscle type for subsequent data normalization, a set of 5 genes (Saremi et al., 2012) was tested and their stability was evaluated using qBASEplus version 2.0 (Biogazelle, Ghent, Belgium). Three reference genes, including low-density lipoprotein receptor-related protein 10 (LRP10), RNA polymerase II (POLR2A), and emerin $(E M D)$, were determined as the most stable reference genes. All subsequent calculations and data quality controls were performed using qBASEplus software (Hellemans et al., 2007). The output data from the software were calibrated normalized relative quantities.

\section{Analysis of Milk and Plasma Samples}

For the determination of free and total AA (TAA) in colostrum and formula, frozen samples were thawed and homogenized carefully, stored at $4^{\circ} \mathrm{C}$ for $2 \mathrm{~h}$, and defatted by centrifugation at $1,000 \times g$ for $20 \mathrm{~min}$ at $4^{\circ} \mathrm{C}$. The remaining whey was diluted by a factor of 4 with pure water. Free AA was determined by HPLC (Series 1200; Agilent) in clear diluted whey after centrifugation at $50,000 \times g$ for $20 \mathrm{~min}$ at $4^{\circ} \mathrm{C}$, whereas the solution had to be hydrolyzed for the analysis of TAA. Therefore, $3.43 \mathrm{~mL}$ of $\mathrm{HCl}$ (30\%, Suprapur, Merck, Darmstadt, Germany) was added to $2 \mathrm{~mL}$ of diluted whey to obtain an acid concentration of $6 \mathrm{~N}$. Oxidation processes were reduced by the addition of ascorbic acid $(50 \mu \mathrm{L}, 16 \mathrm{mg} / \mathrm{mL})$. The solution was incubated under a nitrogen atmosphere at $110^{\circ} \mathrm{C}$ for 22 $\mathrm{h}$, dried under a nitrogen stream at $60^{\circ} \mathrm{C}$, redissolved with $2 \mathrm{~mL}$ of $0.1 \mathrm{~N} \mathrm{HCl}$, and further diluted with pure water by a factor of 100 for HPLC analysis. During the acidic hydrolysis, Trp was destroyed and Cys and Met in part were destroyed; Asn and Gln were converted into Asp and Glu. Protein-bound AA was calculated as the difference of total and free AA. Diluted plasma (10-fold) AA concentrations were analyzed by HPLC (Series 1200; Agilent) as described before (Kuhla et al., 2010). Insulin and IGF-I concentrations were measured by RIA (Baumrucker and Blum, 1994; Hammon and Blum, 1997).

\section{Statistical Analyses}

Statistical analysis of the data was carried out using SAS software (version 9.3; SAS Institute Inc., Cary, $\mathrm{NC}$ ). The data were tested for normality before analysis using the UNIVARIATE procedure. When the data were not normally distributed, they were transformed using a $\log$ (base 10) transformation before analysis. The AA data from blood plasma were analyzed by the 
Table 1. Characteristics of primers and real-time PCR conditions

\begin{tabular}{|c|c|c|c|c|c|c|}
\hline Gene $^{1}$ & Sequence $\left(5^{\prime}-3^{\prime}\right)$ & NCBI accession no. & $\mathrm{bp}^{2}$ & $\begin{array}{c}\text { Concentration } \\
(\mathrm{n} M)\end{array}$ & $\begin{array}{c}\text { Mean } \\
\mathrm{Cq}^{3}\end{array}$ & $\begin{array}{c}\text { Annealing }^{4} \\
\left(\mathrm{~s} /{ }^{\circ} \mathrm{C}\right)\end{array}$ \\
\hline \multicolumn{7}{|l|}{$m T O R$} \\
\hline Forward & CGAAACCCTGGATGTCCCAA & XM_002694043.2 & 94 & 1,000 & 27.1 & $30 / 61$ \\
\hline \multicolumn{7}{|c|}{ (1) } \\
\hline Forward & CGGAACAGTCACACACACCT & NM_205816.1 & 97 & 1,000 & 26.4 & $30 / 61$ \\
\hline Reverse & ACTCCACCAATCCACAGCAC & & & & & \\
\hline \multicolumn{7}{|c|}{ 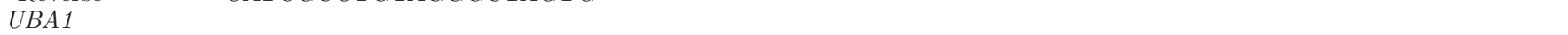 } \\
\hline Forward & GGGGAACCGGCATTGATGT & NM_001102477.1 & 118 & 400 & 26.1 & $60 / 59$ \\
\hline Reverse & AGGGCACTTCGGACAATACG & & & & & \\
\hline \multicolumn{7}{|l|}{ UBE2G1 } \\
\hline Forward & TATGCTGGCAGACCCCAATG & NM_001082458.1 & 109 & 800 & 20.4 & $60 / 59$ \\
\hline 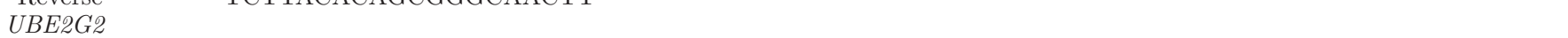 & TCTTACACAGCGGGCAACTT & & & & & \\
\hline \multicolumn{7}{|l|}{ Atrogin-1 } \\
\hline Reverse & TCTTCTTGGCTGCAACGTCA & & & & & \\
\hline \multicolumn{7}{|l|}{ MuRF1 } \\
\hline Forward & CCTGATCCAGGATGGAAACCC & NM_001046295.1 & 149 & 800 & 22.3 & $60 / 59$ \\
\hline Reverse & CAGCCTGCTGGAAGATGTCGT & & & & & \\
\hline \multicolumn{7}{|c|}{ 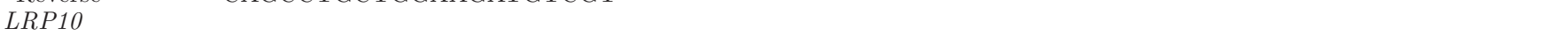 } \\
\hline Forward & CCAGAGGATGAGGACGATGT & BC149232 & 139 & 400 & 24.6 & $30 / 61$ \\
\hline Reverse & ATAGGGTTGCTGTCCCTGTG & & & & & \\
\hline \multicolumn{7}{|l|}{ POLR2A } \\
\hline Forward & GAAGGGGGAGAGACAAACTG & X63564 & 86 & 800 & 25.3 & $60 / 60$ \\
\hline Reverse & GGGAGGAAGAAGAAAAAGGG & & & & & \\
\hline \multicolumn{7}{|c|}{ 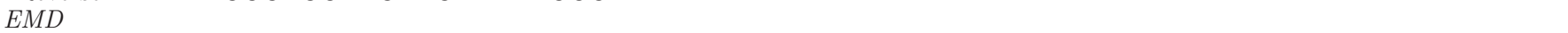 } \\
\hline Forward & GCCСТCAGCTTCACTCTCAGA & NM_203361 & 100 & 400 & 24.1 & $45 / 59$ \\
\hline Reverse & GAGGCGTTCCCGATCCTT & & & & & \\
\hline
\end{tabular}

${ }^{1} m T O R=$ mammalian target of rapamycin; $S 6 K 1=$ ribosomal protein S6 kinase, polypeptide 1; $4 E B P 1=$ eukaryotic translation initiation factor $4 \mathrm{E}$ binding protein 1; UBA1 = ubiquitin-like modifier activating enzyme 1; UBE2G1 = ubiquitin-conjugating enzyme E2G 1; UBE2G2 $=$ ubiquitin-conjugating enzyme E2G 2;MuRF1 = muscle ring-finger protein-1; LRP10 = lipoprotein receptor-related protein $10 ; P O L R 2 A=$ RNA polymerase II; $E M D=$ emerin.

${ }^{2}$ Base pairs.

${ }^{3}$ Mean quantification cycle.

${ }^{4}$ Initial denaturation for $10 \mathrm{~min}$ at $90^{\circ} \mathrm{C}$; denaturation for $30 \mathrm{~s}$ at $95^{\circ} \mathrm{C}$; extension for $30 \mathrm{~s}$ at $72^{\circ} \mathrm{C}$ except for $4 E B P 1, U B A 1, U B E 2 G 1, U B E 2 G 2$, MuRF1 $\left(60 \mathrm{~s}\right.$ at $\left.72^{\circ} \mathrm{C}\right)$, and $\operatorname{LRP} 10\left(20 \mathrm{~s}\right.$ at $\left.72^{\circ} \mathrm{C}\right)$.

MIXED procedure of SAS using repeated measures with a compound symmetry covariance structure. The model included treatment, time (sampling date), and interaction of treatment and time as fixed effects and calf as a random effect. The Tukey-Kramer adjustment was used to account for multiple comparisons. In the case of statistical evaluation of the mRNA data, treatment, muscle, and interaction of treatment and muscle were used as fixed effects. Calf was used as the repeated subject. Data are presented as means \pm standard errors of the mean. Statistical significance was declared at $P$ $\leq 0.05$, and a trend to significance was declared at 0.05 $<P \leq 0.10$. The CORR procedure of SAS was applied to calculate correlations between insulin, IGF-I, and AA.

\section{RESULTS}

\section{Composition of Colostrum and Formula}

Free and protein-bound AA composition of colostrum and formula are given in Supplemental Tables S1 and S2 (https://doi.org/10.3168/jds.2017-12857). Colostrumand formula-fed calves consumed the same amounts of lactose and other macronutrients such as gross energy, CP, and fat (Steinhoff-Wagner et al., 2011), whereas colostrum-fed calves had greater concentrations of free Leu, Ile, Val, branched-chain AA (BCAA), total EAA, and nonessential AA than formula-fed calves. Proteinbound AA concentrations in formula were almost comparable with those of colostrum. Colostrum fed on $d 1$ 
contained greater concentrations of insulin (34 vs. 12 $\mu \mathrm{g} / \mathrm{L}$ ) than formula, whereas concentrations of insulin on other days were comparable. Moreover, colostrum had greater concentrations of IGF-I (24.9-, 25.6-, and 5.75-fold on d 1,2, and 3 and 4, respectively) than formula (Steinhoff-Wagner et al., 2011).

\section{Preprandial Plasma AA, Dipeptides, and Hormone Concentrations}

The concentrations of preprandial plasma AA and dipeptides are presented in Table 2. Plasma Ala, anserine, Asp, carnosine, Cit, Gly, His, Lys, Met, Orn, Phe, Pro, Tau, Trp, Val, and 3-methylhistidine concentrations were not different between groups, but their concentrations changed over time $(P \leq 0.05)$. Plasma Arg concentrations increased $(P<0.01)$ during the first $48 \mathrm{~h}$ in both groups and were lower $(P<0.01)$ from 48 to $72 \mathrm{~h}$ in COL than in FOR. Plasma Asn concentrations increased $(P<0.01)$ during the first 48 $\mathrm{h}$ in COL and tended to be lower $(P=0.08)$ in FOR than in COL. Plasma Cys concentrations changed over time in COL and $24 \mathrm{~h}$ after birth were lower in COL than in FOR. Plasma Gln concentrations decreased $(P$ $<0.01)$ during the first $24 \mathrm{~h}$ in COL and were lower $(P$ $<0.01$ ) in COL than in FOR from 48 to $72 \mathrm{~h}$. Plasma Glu was elevated at 24 and $48 \mathrm{~h}$ compared with 0 and $72 \mathrm{~h}$ in COL and was lower in FOR than in COL $(P<$ $0.01)$ from 24 to $72 \mathrm{~h}$. Plasma hydroxyproline changed over time $(P=0.01)$ and was higher $(P=0.01)$ in COL than in FOR. Plasma Ile concentrations increased $(P$ $=0.01$ ) during the first $24 \mathrm{~h}$ to a higher concentration in FOR than in COL and from 48 to $72 \mathrm{~h}$ decreased in FOR. Plasma Leu concentrations were increased $(P$ $<0.01$ ) 3 - and 4.4-fold in COL and FOR, respectively, from 0 to $24 \mathrm{~h}$ and decreased from 48 to $72 \mathrm{~h}$; they were 1.8-fold greater $(P=0.01)$ in FOR than in COL $24 \mathrm{~h}$ after birth. The plasma Ser concentrations increased $(P=0.05)$ during the first $48 \mathrm{~h}$ in $\mathrm{COL}$ and were higher $(P<0.01)$ at $24 \mathrm{~h}$ in COL than in FOR. Plasma Thr concentrations increased $(P<0.01)$ in COL from 0 to $48 \mathrm{~h}$ and in FOR during the first 24 $\mathrm{h}$ and were higher at 48 and $72 \mathrm{~h}$ after birth in COL than in FOR. Plasma Tyr concentrations increased $(P$ $<0.01$ ) during the first $24 \mathrm{~h}$ and then decreased up to $72 \mathrm{~h}$ and were higher $(P=0.05)$ at $48 \mathrm{~h}$ in COL than in FOR. Free plasma TAA concentrations changed over time $(P<0.001)$ and followed a similar pattern in both groups - that is, they increased during the first $24 \mathrm{~h}$ and then decreased from 48 to $72 \mathrm{~h}$ (Figure 1). There was a trend $(P=0.08)$ for greater plasma concentrations of free plasma BCAA in FOR than in COL (Figure 1). The concentrations of free BCAA in plasma increased in both groups from 0 to $48 \mathrm{~h}$ after birth and then decreased from 48 to $72 \mathrm{~h}(P=0.001$; Figure 1). Plasma IGF-I concentrations were not different between groups, but their concentrations increased $(P<$ 0.05 ) during the first $24 \mathrm{~h}$ and then decreased up to 72 $\mathrm{h}$ after birth in both groups (Figure 1). Plasma insulin concentrations were increased in both groups at $24 \mathrm{~h}$ after birth and then subsequently decreased up to $72 \mathrm{~h}$ $(P<0.01 ;$ Figure 1$)$.

\section{Postprandial Changes of Plasma AA, Dipeptides, and Hormone Concentrations}

The postprandial changes of plasma AA and dipeptides on d 4 are presented in Table 3. Plasma Ala, Glu, and Ser concentrations decreased $(P<0.01)$ after feeding in group COL. Plasma Ala and Glu concentrations were lower $(P<0.01)$ before feeding and plasma Ser concentration was lower and Glu was higher after feeding $(P<0.01)$ in COL than in FOR. Plasma anserine, carnosine, and 3-methylhistidine concentrations were not affected by group or time. Plasma Arg, Asn, Cit, Gln, and Thr concentrations increased $(P<0.01)$ after feeding in FOR, and plasma Arg and Thr concentrations were lower $(P<0.01)$ before feeding, whereas plasma Gln concentrations were higher $(P<0.01)$ before and after feeding in FOR than in COL. Plasma Asp, His, Met, Phe, and Val concentrations changed $(P<0.01)$ inversely after feeding in COL compared with FOR. In addition, plasma Cys concentrations were higher and Met concentrations were lower before feeding in FOR than in COL; the plasma concentrations of Asp, Cys, Met, Phe, and Val were higher $(P<0.01)$ after feeding in FOR than in COL. Plasma Gly concentration decreased $(P<0.01)$, whereas that of Trp increased $(P<$ $0.01)$ with feeding in both groups. Plasma hydroxyproline was overall higher in COL than in FOR $(P<0.01)$. The plasma concentrations of Ile, Leu, Lys, Orn, Pro, Tau, and Tyr increased $(P \leq 0.05)$ after feeding only in FOR, resulting in higher $(P \leq 0.05)$ postprandial Ile, Leu, Orn, and Tyr concentrations in FOR than in COL. The concentrations of free TAA and BCAA in plasma decreased $(P<0.01)$ in COL, whereas they increased $(P<0.01)$ in FOR after feeding, resulting in higher $(P$ $<0.05)$ postprandial plasma TAA and BCAA concentrations in FOR than in COL (Figure 1). The plasma concentrations of IGF-I slightly decreased $(P<0.05)$ in COL, whereas they remained unchanged in FOR after feeding (Figure 1). Plasma insulin concentrations increased $(P<0.05)$ in both groups after feeding but to a greater extent in $\mathrm{COL}$ than in FOR, resulting in higher $(P<0.01)$ postprandial insulin concentrations in COL than in FOR (Figure 1). 
Table 2. Preprandial plasma AA and dipeptide concentrations ( $\mu \mathrm{mol} / \mathrm{L})$ in calves fed colostrum (COL) or formula (FOR) for $4 \mathrm{~d}$

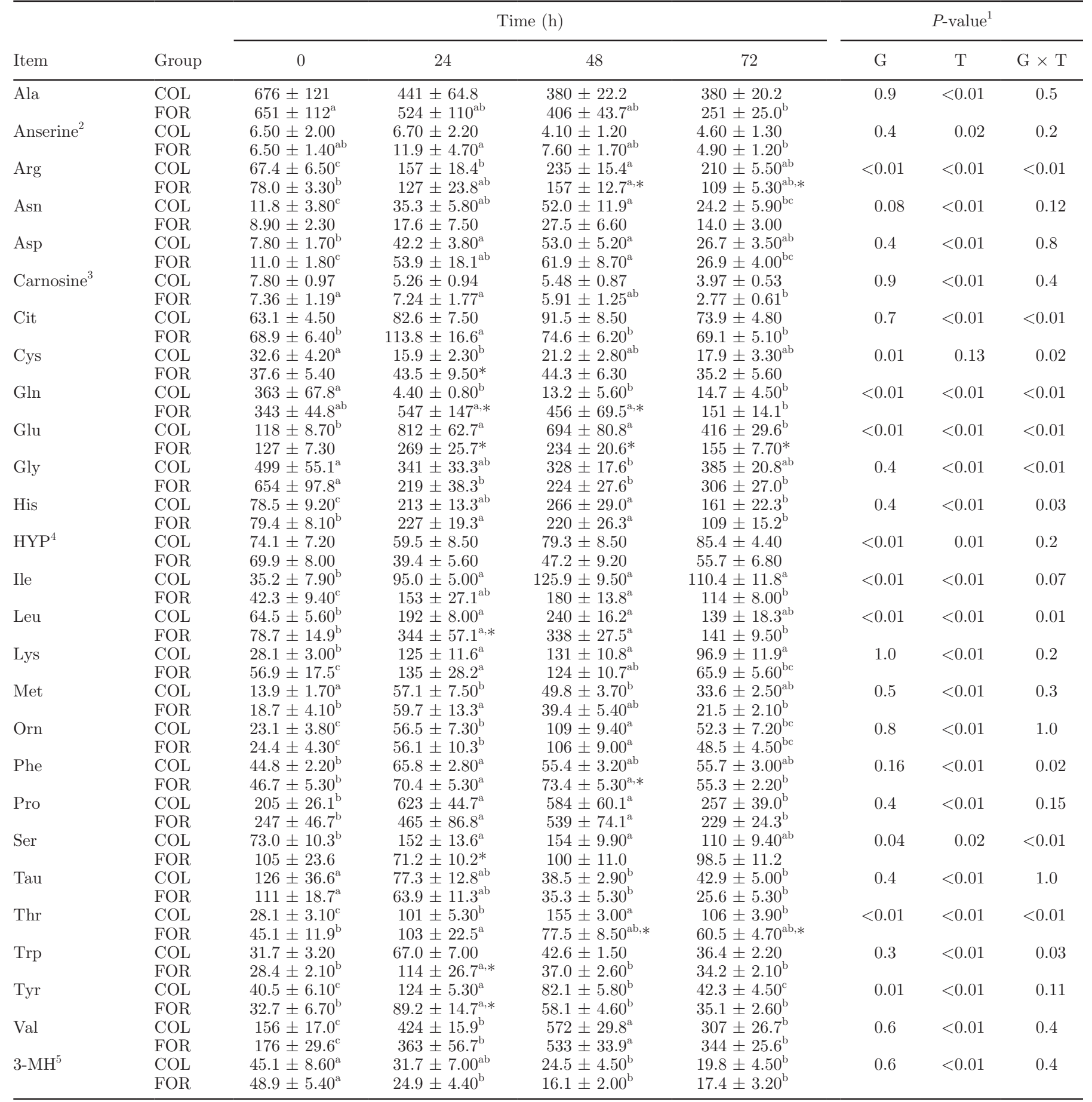

${ }^{\mathrm{a}-\mathrm{c}}$ Means within a row with different superscripts differ $(P<0.05)$.

${ }^{1}$ Statistical comparisons: $\mathrm{G}=$ group effect; $\mathrm{T}=$ time effect; $\mathrm{G} \times \mathrm{T}=$ group $\times$ time interaction.

${ }^{2}$ Dipeptide ( $\beta$-alanyl-1- $N$-methyl-L-His).

${ }^{3}$ Dipeptide ( $\beta$-alanyl-L-His).

${ }^{4}$ Hydroxyproline.

${ }^{5} 3$-Methylhistidine.

*Different from COL $(P<0.05)$. 

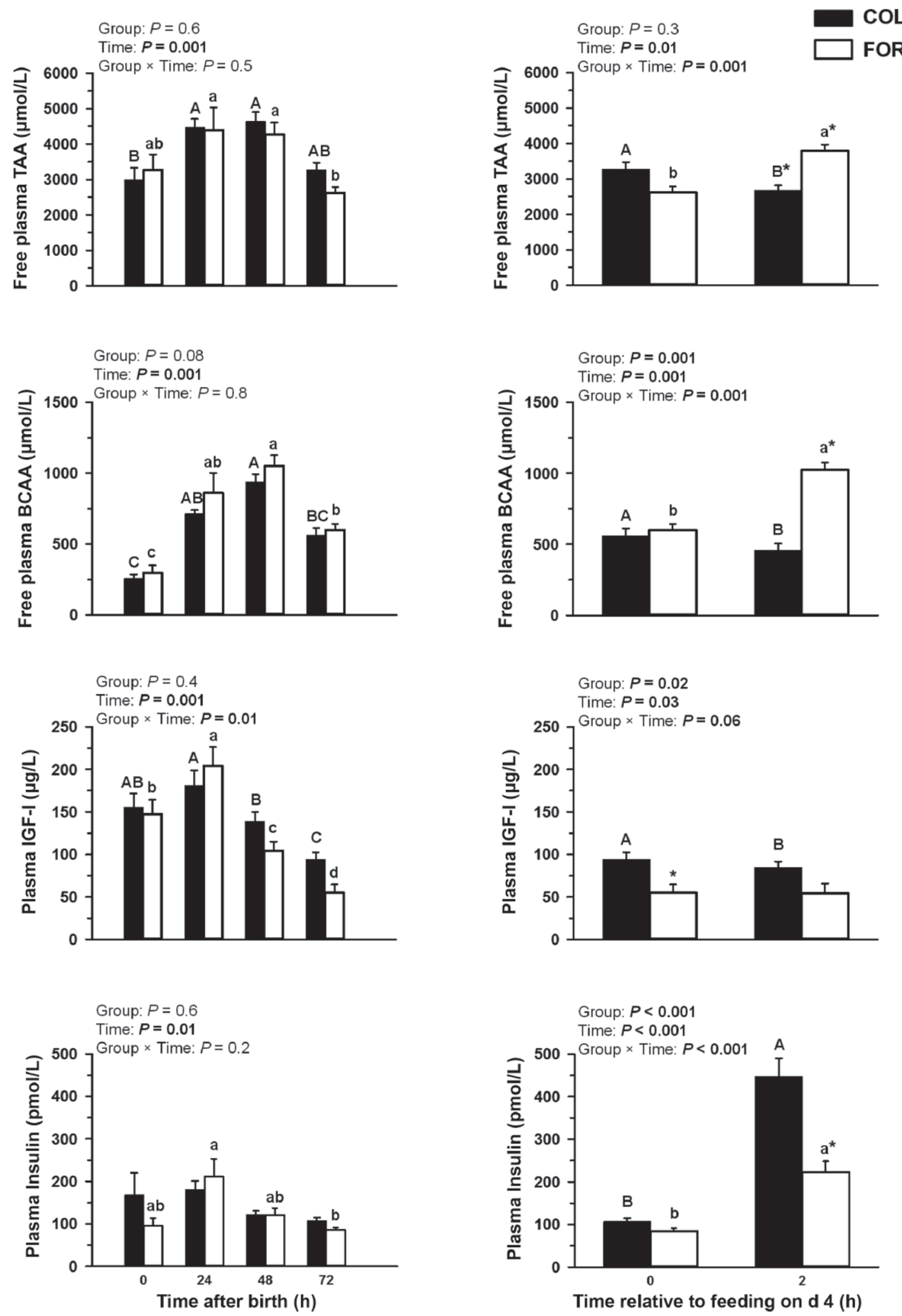

Figure 1. Left panel: Preprandial plasma total AA (TAA) and branched-chain AA (BCAA), IGF-I, and insulin concentrations of calves fed colostrum (COL) or formula (FOR) for the first $4 \mathrm{~d}$ after birth. Right panel: Plasma TAA, BCAA, IGF-I, and insulin before $(0 \mathrm{~h})$ and $2 \mathrm{~h}$ after feeding on d 4 of life. Different letters indicate differences $(P<0.05)$ between 3 different skeletal muscles in the COL group (A-C) and the FOR group (a-d). Asterisks indicate a significant difference $(P<0.05)$ between COL and FOR at a given muscle. Data for IGF-I and insulin are from Schäff et al. (2014) and Steinhoff-Wagner et al. (2011), respectively. Data are presented as means \pm SEM. 
Table 3. Plasma AA and dipeptide concentrations ( $\mu \mathrm{mol} / \mathrm{L})$ before $(0 \mathrm{~h})$ and $2 \mathrm{~h}$ after feeding in calves fed colostrum (COL) or formula (FOR) on d 4 of life

\begin{tabular}{|c|c|c|c|c|c|c|}
\hline \multirow[b]{2}{*}{ Item } & \multirow[b]{2}{*}{ Group } & \multicolumn{2}{|c|}{ Time (h) } & \multicolumn{3}{|c|}{$P$-value ${ }^{1}$} \\
\hline & & 0 & 2 & G & $\mathrm{T}$ & $\mathrm{G} \times \mathrm{T}$ \\
\hline \multirow[t]{2}{*}{ Ala } & $\mathrm{COL}$ & $380 \pm 20.2^{\mathrm{a}}$ & $294 \pm 9.30^{\mathrm{b}}$ & 0.02 & $<0.01$ & $<0.01$ \\
\hline & FOR & $251 \pm 25.0^{*}$ & $279 \pm 20.4$ & & & \\
\hline \multirow{2}{*}{ Anserine $^{2}$} & $\mathrm{COL}$ & $4.60 \pm 1.30$ & $5.80 \pm 1.30$ & 1 & 0.19 & 0.7 \\
\hline & FOR & $4.90 \pm 1.20$ & $5.60 \pm 0.70$ & & & \\
\hline \multirow[t]{2}{*}{ Arg } & $\mathrm{COL}$ & $210 \pm 5.50$ & $183 \pm 9.00$ & $<0.01$ & 0.14 & $<0.01$ \\
\hline & FOR & $109 \pm 5.30^{\mathrm{b}, *}$ & $166 \pm 18.7^{\mathrm{a}}$ & & & \\
\hline \multirow[t]{2}{*}{ Asn } & $\mathrm{COL}$ & $24.2 \pm 5.90$ & $18.0 \pm 3.90$ & 0.9 & 0.01 & $<0.01$ \\
\hline & FOR & $14.0 \pm 3.00^{\mathrm{b}}$ & $30.4 \pm 4.70^{\mathrm{a}}$ & & & \\
\hline \multirow[t]{2}{*}{ Asp } & $\mathrm{COL}$ & $26.7 \pm 3.50^{\mathrm{a}}$ & $19.1 \pm 1.70^{\mathrm{b}}$ & 0.04 & 0.03 & $<0.01$ \\
\hline & FOR & $26.9 \pm 4.00^{\mathrm{b}}$ & $43.6 \pm 6.00^{\mathrm{a}, *}$ & & & \\
\hline \multirow{2}{*}{ Carnosine $^{3}$} & $\mathrm{COL}$ & $3.97 \pm 0.53$ & $4.32 \pm 0.42$ & 0.15 & 0.4 & 0.7 \\
\hline & FOR & $2.77 \pm 0.61$ & $3.54 \pm 0.80$ & & & \\
\hline \multirow[t]{2}{*}{ Cit } & $\mathrm{COL}$ & $73.9 \pm 4.80$ & $64.4 \pm 4.30$ & 0.15 & 0.09 & $<0.01$ \\
\hline & FOR & $69.1 \pm 5.10^{\mathrm{b}}$ & $88.8 \pm 5.50^{\mathrm{a}, *}$ & & & \\
\hline \multirow[t]{2}{*}{ Cys } & $\mathrm{COL}$ & $17.9 \pm 3.30$ & $16.0 \pm 3.10$ & $<0.01$ & 0.7 & 0.5 \\
\hline & FOR & $35.2 \pm 5.60^{*}$ & $35.9 \pm 2.80^{*}$ & & & \\
\hline \multirow[t]{2}{*}{ Gln } & $\mathrm{COL}$ & $14.7 \pm 4.50$ & $11.7 \pm 3.20$ & $<0.01$ & $<0.01$ & $<0.01$ \\
\hline & FOR & $151 \pm 14.1^{\mathrm{b}, *}$ & $228 \pm 17.1^{\mathrm{a}, *}$ & & & \\
\hline \multirow[t]{2}{*}{ Glu } & $\mathrm{COL}$ & $416 \pm 29.6^{\mathrm{a}}$ & $340 \pm 16.9^{\mathrm{b}}$ & $<0.01$ & $<0.01$ & $<0.01$ \\
\hline & FOR & $155 \pm 7.70^{*}$ & $173 \pm 6.80^{*}$ & & & \\
\hline \multirow[t]{2}{*}{ Gly } & $\mathrm{COL}$ & $385 \pm 20.8^{\mathrm{a}}$ & $255 \pm 14.9^{\mathrm{b}}$ & 0.3 & $<0.01$ & $<0.01$ \\
\hline & FOR & $306 \pm 27.0^{\mathrm{a}}$ & $274 \pm 23.2^{\mathrm{b}}$ & & & \\
\hline \multirow[t]{2}{*}{ His } & COL & $161 \pm 22.3^{\mathrm{a}}$ & $131 \pm 16.1^{\mathrm{b}}$ & 0.4 & 0.5 & $<0.01$ \\
\hline & FOR & $109 \pm 15.2^{\mathrm{b}}$ & $144 \pm 14.7^{\mathrm{a}}$ & & & \\
\hline \multirow[t]{2}{*}{$\mathrm{HYP}^{4}$} & $\mathrm{COL}$ & $85.4 \pm 4.40$ & $71.1 \pm 13.4$ & $<0.01$ & 0.1 & 1.0 \\
\hline & FOR & $55.7 \pm 6.80$ & $41.9 \pm 3.10$ & & & \\
\hline \multirow[t]{2}{*}{ Ile } & $\mathrm{COL}$ & $110 \pm 11.8$ & $95.1 \pm 9.70$ & $<0.01$ & $<0.01$ & $<0.01$ \\
\hline & FOR & $114 \pm 8.00^{\mathrm{b}}$ & $210 \pm 9.30^{\mathrm{a}, *}$ & & & \\
\hline Leu & $\mathrm{COL}$ & $139 \pm 18.3$ & $115 \pm 13.7$ & $<0.01$ & $<0.01$ & $<0.01$ \\
\hline & FOR & $141 \pm 9.40^{\mathrm{b}}$ & $312 \pm 17.8^{\mathrm{a}, *}$ & & & \\
\hline Lys & $\mathrm{COL}$ & $96.9 \pm 11.9$ & $107 \pm 10.7$ & 0.6 & $<0.01$ & $<0.01$ \\
\hline & FOR & $65.9 \pm 5.60^{\mathrm{b}}$ & $158 \pm 21.9^{\mathrm{a}}$ & & & \\
\hline Met & $\mathrm{COL}$ & $33.6 \pm 2.50^{\mathrm{a}}$ & $23.1 \pm 2.20^{\mathrm{b}}$ & 0.8 & 0.14 & $<0.01$ \\
\hline & FOR & $21.5 \pm 2.10^{\mathrm{b}, *}$ & $36.8 \pm 2.90^{\mathrm{a}, *}$ & & & \\
\hline Orn & COL & $52.3 \pm 7.20$ & $49.2 \pm 6.40$ & 0.02 & $<0.01$ & $<0.01$ \\
\hline & FOR & $48.5 \pm 4.50^{\mathrm{b}}$ & $98.3 \pm 7.60^{\mathrm{a}, *}$ & & & \\
\hline Phe & $\mathrm{COL}$ & $55.7 \pm 3.00^{\mathrm{a}}$ & $43.3 \pm 2.90^{\mathrm{b}}$ & $<0.01$ & $<0.01$ & $<0.01$ \\
\hline & FOR & $55.3 \pm 2.20^{\mathrm{b}}$ & $89.9 \pm 4.40^{\mathrm{a}, *}$ & & & \\
\hline Pro & $\mathrm{COL}$ & $257 \pm 39.0$ & $206 \pm 25.8$ & 0.09 & 0.02 & $<0.01$ \\
\hline & FOR & $229 \pm 24.3^{\mathrm{b}}$ & $381 \pm 33.8^{\mathrm{a}, *}$ & & & \\
\hline Ser & $\mathrm{COL}$ & $110 \pm 9.40^{\mathrm{a}}$ & $74.0 \pm 4.70^{\mathrm{b}}$ & 0.3 & 0.04 & $<0.01$ \\
\hline & FOR & $98.5 \pm 11.2$ & $115 \pm 11.3^{*}$ & & & \\
\hline Tau & $\mathrm{COL}$ & $42.9 \pm 5.00$ & $50.4 \pm 5.40$ & 0.7 & $<0.01$ & 0.03 \\
\hline & FOR & $25.6 \pm 5.30^{\mathrm{b}}$ & $75.1 \pm 15.1^{\mathrm{a}}$ & & & \\
\hline Thr & $\mathrm{COL}$ & $106 \pm 3.90$ & $94.9 \pm 4.70$ & 0.03 & $<0.01$ & $<0.01$ \\
\hline & FOR & $60.5 \pm 4.60^{\mathrm{b}, *}$ & $104 \pm 8.10^{\mathrm{a}}$ & & & \\
\hline $\operatorname{Trp}$ & $\mathrm{COL}$ & $36.4 \pm 2.20^{\mathrm{b}}$ & $44.2 \pm 3.20^{\mathrm{a}}$ & 0.6 & $<0.01$ & 0.6 \\
\hline & FOR & $34.2 \pm 2.10^{\mathrm{b}}$ & $43.6 \pm 1.50^{\mathrm{a}}$ & & & \\
\hline Tyr & $\mathrm{COL}$ & $42.3 \pm 4.50$ & $37.9 \pm 2.70$ & $<0.01$ & $<0.01$ & $<0.01$ \\
\hline & FOR & $35.1 \pm 2.60^{\mathrm{b}}$ & $86.1 \pm 5.40^{\mathrm{a}, *}$ & & & \\
\hline Val & $\mathrm{COL}$ & $307 \pm 26.7^{\mathrm{a}}$ & $247 \pm 23.7^{\mathrm{b}}$ & $<0.01$ & $<0.01$ & $<0.01$ \\
\hline & FOR & $344 \pm 25.6^{\mathrm{b}}$ & $501 \pm 26.0^{\mathrm{a}, *}$ & & & \\
\hline $3-\mathrm{MH}^{5}$ & $\mathrm{COL}$ & $19.8 \pm 4.50$ & $23.3 \pm 4.70$ & 0.4 & 0.5 & 0.6 \\
\hline & FOR & $17.4 \pm 3.20$ & $17.8 \pm 2.40$ & & & \\
\hline
\end{tabular}

${ }_{\mathrm{a}, \mathrm{b}}$ Means within a row with different superscripts differ $(P<0.05)$.

${ }^{1}$ Statistical comparisons: $\mathrm{G}=$ group effect; $\mathrm{T}=$ time effect; $\mathrm{G} \times \mathrm{T}=$ group $\times$ time interaction.

${ }^{2}$ Dipeptide ( $\beta$-alanyl-1- $N$-methyl-L-His).

${ }^{3}$ Dipeptide ( $\beta$-alanyl-L-His).

${ }^{4}$ Hydroxyproline.

${ }^{5} 3$-Methylhistidine.

*Different from COL $(P<0.05)$. 


\section{mRNA Abundance of Genes in 3 Different Skeletal Muscles}

As presented in Figure 2, the abundance of $m T O R$ mRNA was greater (MLD and MST, $P \leq 0.03$ ) or tended to be greater (MM, $P=0.07$ ) in COL than in FOR. The mRNA abundance of ribosomal protein S6 kinase 1 (S6K1) in the 3 different skeletal muscles was greater $(P<0.001)$ in COL than in FOR, whereas that of eukaryotic translation initiation factor $4 \mathrm{E}$ binding protein 1 ( $4 E B P 1)$ was unaffected by diet. The mRNA abundance of $m T O R, S 6 K 1$, and $4 E B P 1$ was not affected by muscle type, and there was no group $\times$ muscle interaction. The mRNA abundance of ubiquitin activating enzyme (UBA1) was not affected by group or muscle type, and there was no group $\times$ muscle interaction (Figure 3). Muscle-related changes in the mRNA abundance of ubiquitin conjugating enzyme 1 (UBE2G1) were noted in both experimental groups $(P$ $<0.001)$; that is, it was greater in MLD than in MST and MM. The abundance of ubiquitin conjugating enzyme 2 (UBE2G2) mRNA was greater (MLD, $P=0.02$ ) or tended to be greater (MM, $P=0.10)$ in $\mathrm{COL}$ than in FOR. The mRNA abundance of UBE2G2 was not affected by muscle type or group $\times$ muscle interaction (Figure 3). The mRNA abundance of atrogin-1 in MLD and MST was lower $(P \leq 0.03)$, whereas that of muscle ring finger protein-1 $(M u R F 1)$ was greater (MST, $P$ $<0.001$ ) or tended to be greater (MLD, $P=0.10$ ) in COL than in FOR. Muscle type-related changes in the abundance of MuRF1 mRNA were detected in both groups $(P<0.001)$; it was highest in abundance in MST, followed by MLD, and was lowest in MM (Figure 3 ). A group $\times$ muscle interaction was observed for the abundance of MuRF1 mRNA $(P=0.03)$.

\section{Correlation Among Plasma Concentrations of Insulin, IGF-I, and AA}

Correlation among plasma concentrations of insulin, IGF-I, and AA is shown in Supplemental Figure S1 (https://doi.org/10.3168/jds.2017-12857). Plasma insulin was negatively correlated with plasma Ala, Glu, Met, and total nonessential AA in COL on d 4 (across time; $-0.61<\mathrm{r}<-0.54 ; P<0.04$ ). In addition, negative correlations were noted between plasma insulin and plasma Asp, Gln, Lys, Met, Tyr, BCAA, EAA, nonessential AA, and TAA postprandial (across groups; $-0.87<\mathrm{r}<-0.56 ; P<0.04)$. Most correlations between IGF-I and AA (Ala, Arg, Glu, Met, and Thr) were observed preprandial (across groups; $0.53<$ r $<0.67 ; P<0.04)$.
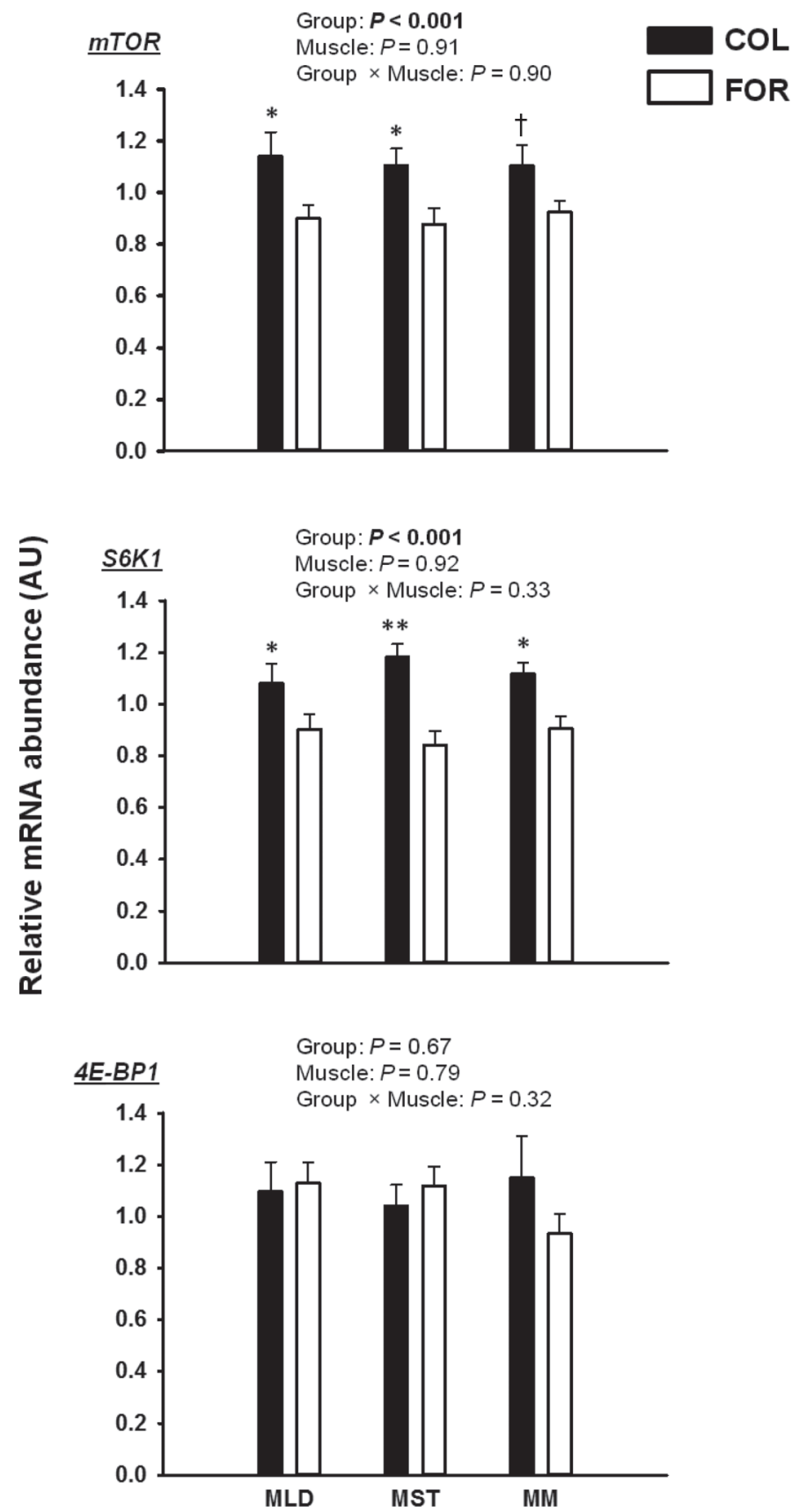

Figure 2. The mRNA abundance of genes related to the mammalian target of rapamycin $(m T O R)$ pathway in 3 different skeletal muscles (MLD = M. longissiumus dorsi; MST = M. semitendonosus; $\mathrm{MM}=\mathrm{M}$. masseter) of calves fed colostrum $(\mathrm{COL})$ or formula $(\mathrm{FOR})$. Symbols indicate a significant difference $\left({ }^{*} P<0.05 ;{ }^{* *} P<0.01\right)$ or a trend $(\dagger P<0.10)$ between COL and FOR at a given muscle. S6K1 $=$ ribosomal protein $\mathrm{S} 6$ kinase, polypeptide 1; $4 E B P 1=$ eukaryotic translation initiation factor $4 \mathrm{E}$ binding protein. Data are presented as means \pm SEM. 

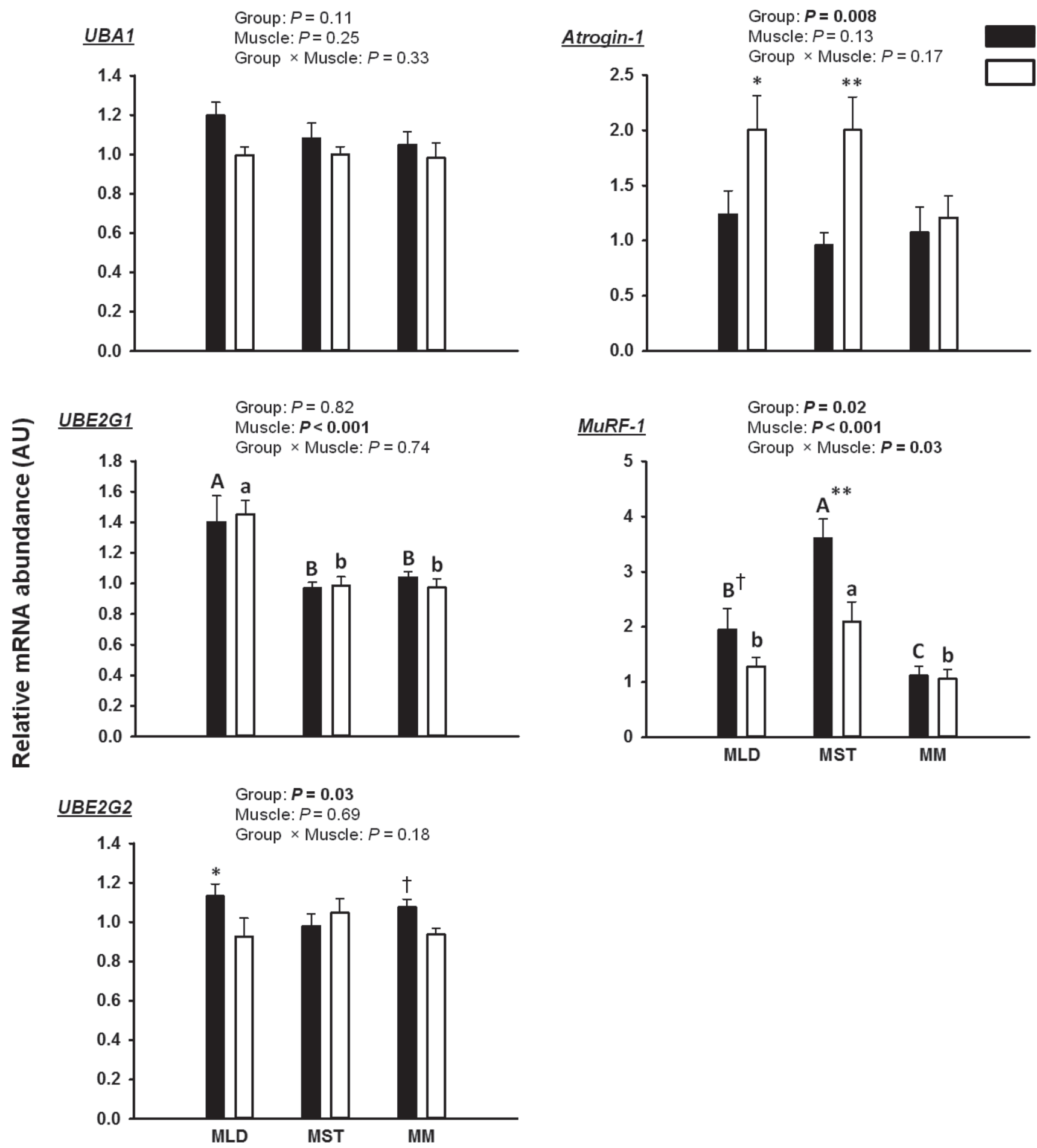

Figure 3. The mRNA abundance of genes related to the ubiquitin-proteasome system in 3 different skeletal muscles (MLD = M. longissiumus dorsi; MST $=$ M. semitendonosus; $\mathrm{MM}=\mathrm{M}$. masseter) of calves fed colostrum (COL) or formula (FOR). Different letters indicate differences $(P<0.05)$ between 3 different skeletal muscles in the COL group $(\mathrm{A}-\mathrm{C})$ and the FOR group (a,b). Symbols indicate a significant difference $\left({ }^{*} P<0.05 ;{ }^{* *} P<0.01\right)$ or a trend $(\dagger P<0.1)$ between $\mathrm{COL}$ and FOR at a given muscle. $U B A 1=$ ubiquitin-like modifier activating enzyme 1 ; UBE2G1 and UBE2G2 = ubiquitin-conjugating enzymes; MuRF1 = muscle ring-finger protein-1. Data are presented as means \pm SEM. 


\section{DISCUSSION}

The current data suggest that feeding colostrum might stimulate muscle protein turnover in neonatal calves, as indicated by the changes in transcript abundance of key components of mTOR signaling ( $m$ TOR and S6K1) and of the UBE2G2 and muscle-specific E3 ubiquitin ligases (MuRF1 and atrogin-1) in a muscle type-specific manner. The observed responses may be a consequence of either altered metabolic and endocrine status or provision of different nutrient composition or additional growth factors by colostrum that are barely provided through formula. The response to feeding colostrum or formula was associated with metabolic and endocrine changes as reported previously (Steinhoff-Wagner et al., 2011; Schäff et al., 2014). Plasma glucose concentrations were greater in COL than in FOR throughout the study despite similar lactose intakes in both groups. Greater plasma glucose concentrations in the colostrum-fed calves were associated with greater postprandial insulin concentrations on $\mathrm{d}$ 4. The data showed that the improved glucose status in colostrum-fed calves resulted from enhanced intestinal glucose absorption rather than from gluconeogenesis (Steinhoff-Wagner et al., 2011). This higher absorption was mediated by better development of the intestinal epithelia in colostrum-fed calves (Steinhoff-Wagner et al., 2014), which likely increases the absorptive capacity for glucose (Steinhoff-Wagner et al., 2011) as well as AA. However, better gut development in colostrum-fed calves required a higher demand of AA for intestinal protein synthesis. The AA concentrations in the plasma mirror the expected pattern for newborn calves fed colostrum (Hammon and Blum, 1999; Zanker et al., 2000), but plasma appearance of AA in FOR is much higher compared with previous studies with milk replacer (Hammon and Blum, 1999), probably due to the higher CP content in the diet $(220 \mathrm{~g} / \mathrm{kg}$ of DM in milk replacer vs. $338 \mathrm{~g} / \mathrm{kg}$ of DM in formula fed on d 4). Furthermore, the elevated plasma urea concentrations pointed to a greater AA degradation in formula-fed calves than in colostrum-fed calves, probably to provide substrates for gluconeogenesis and to compensate for lower intestinal absorptive capacity for glucose (Steinhoff-Wagner et al., 2011). On the other hand, plasma BCAA and TAA concentrations decreased in COL, whereas they increased in FOR after feeding at $\mathrm{d} 4$, resulting in lower postprandial plasma BCAA and TAA concentrations in COL than in FOR. No changes in plasma urea concentrations were found in regard to feeding in both groups (Steinhoff-Wagner et al., 2011). Both suggest that the postprandial increase in plasma insulin probably stimulated tissue AA uptake, resulting in increased availability of AA for protein synthesis. Besides many functions, insulin is well known to stimulate glucose and AA uptake from blood into various tissues. This is coupled with stimulation of anabolic processes, including protein syntheses in muscle, adipose tissue, liver, and other tissues, as well as a decrease of protein degradation in muscle and probably other tissues (Dimitriadis et al., 2011). Taken together, this pattern of circulating insulin and AA concentrations indicates that the postprandial increase in plasma insulin is most likely to stimulate (directly or indirectly through increasing AA uptake from circulation) protein deposition in skeletal muscle of colostrum-fed calves. Protein synthesis, one of the most energy-demanding cellular processes, is activated only under energetically favorable conditions (Albert and Hall, 2015). Insulin and AA - in particular BCAA - are known as critical factors mediating the stimulation of muscle protein synthesis in response to feeding (Davis et al., 2010). Several studies suggest that mTOR integrates AA and insulin signals through multiple mechanisms including activation of S6K1 and 4E-BP1, the 2 best-characterized regulators of protein synthesis downstream of mTORC1 (Proud, 2006; Davis et al., 2010). Indeed, the mTOR senses nutrient availability, particularly AA (Hay and Sonenberg, 2004). Among AA, Leu is known as the most effective activator of mTORC1 (Thomas et al., 2014). Thus, the potential stimulatory effect of colostrum on protein synthesis might also be produced by insulinmediated increased Leu levels in muscle, resulting in stimulation of mTOR and its downstream signaling pathway. However, we could not evaluate the effects of feeding colostrum or formula on muscle protein synthesis or muscle weighs; it thus remains to be elucidated to what extent the observed regulation of mTOR and the UPS at the transcriptional level may correlate with protein synthesis rates. However, the stimulatory effect of colostrum on protein synthesis in visceral and skeletal muscle tissues has already been demonstrated in neonatal pigs (Burrin et al., 1992). Burrin et al. (1992) found that after only $6 \mathrm{~h}$ of feeding, the rates of skeletal muscle protein synthesis in colostrum-fed pigs was $50 \%$ greater than in pigs fed mature milk.

In the present study, the potential significance of intestinal absorption of colostrum-borne insulin and IGFI is unlikely despite greater concentration of insulin and IGF-I in colostrum than in formula. Administration of bovine insulin to newborn calves immediately preceding first colostrum did not affect circulating insulin or blood glucose, indicating that insulin is not absorbed from the intestine at significant rates (Grütter and Blum, 1991). In support of this notion, the potential significance of intestinal absorption of insulin from ingested colostrum 
in newborn pigs appeared to be minimal (Burrin et al., 1995). In the current study, preprandial plasma IGF-I concentrations were not different between groups, and there was no increase in plasma IGF-I after feeding on $\mathrm{d}$ 4. Thus, the observed responses to feeding colostrum cannot be attributed to circulating IGF-I that is unlikely to have originated from intestinal absorption of colostrum-borne IGF-I and, most undoubtedly, from endogenous secretion. Therefore, on the basis of the previous studies (Grütter and Blum, 1991; Baumrucker and Blum, 1994; Vacher et al., 1995; Blum and Hammon, 2000) and on our observations, ingested colostral hormones and growth factors (e.g., insulin and IGF) may only marginally pass into circulation in newborn calves and exert their effects primarily locally in the gastrointestinal tract. This may lead to the stimulation of intestinal growth and thus absorptive capacity in neonatal calves (Steinhoff-Wagner et al., 2014).

The UPS, the main proteolytic pathway in skeletal muscle, is highly regulated in the cells with crucial involvement of MuRF1 and atrogin-1 abundance, known as 2 major muscle-specific E3 ubiquitin ligases to control the ubiquitination and degradation of target proteins (Bodine et al., 2001; Gomes et al., 2001; Foletta et al., 2011). Indeed, these atrophy-regulated genes, or atrogenes, target specific proteins for polyubiquitylation and subsequent degradation through the $26 \mathrm{~S}$ proteasome pathway (Foletta et al., 2011). Atrogin-1 targets the myogenic transcription factors $\mathrm{MyoD}$ and myogenin as protein substrates, thus suggesting a role for atrogin-1 in the regulation of myoblast differentiation and muscle size (Foletta et al., 2011). In contrast to atrogin-1, MuRF-1 preferentially binds to and degrades structural proteins such as titin (Centner et al., 2001) and myosin light chain 1 and 2 (Cohen et al., 2009). In a review of published studies, Foletta et al. (2011) proposed that atrogin-1 may regulate the substrate targets affecting protein synthesis and muscle growth, whereas MuRF-1 is likely involved in the control of protein degradation and probably also contributes to skeletal muscle metabolism. In the current study, the differential response of the 2 ligases, atrogin-1 and $M u R F 1$, to feeding colostrum coincided with the greater abundance of $m T O R$ and $S 6 K 1 \mathrm{mRNA}$, further supporting the potential stimulatory effect of colostrum on muscle protein deposition. Indeed, upregulation of MuRF1 and key components of mTOR at the level of the mRNA may show a higher rate of protein turnover in muscle of COL calves compared with FOR calves. The higher rates of protein turnover may allow for a continuous flow of AA to be available for the synthesis of new proteins, thus supporting the high rate of protein deposition.
Our data show that the expression of mTOR signaling and UPS-related genes in skeletal muscle of neonatal calves was divergently affected by colostrum versus formula feeding. Skeletal muscle, a heterogeneous and highly structured tissue, consists of a set of fiber types that have different functional and metabolic profiles (Gunawan et al., 2007). As a consequence, each fiber type may respond differently to diet or treatment. Studies in neonatal pigs suggested that the response of skeletal muscle to anabolic signals (e.g., insulin and Leu) that stimulate muscle protein synthesis is fiber type dependent. The response in MLD, a muscle containing primarily fast-twitch glycolytic fibers (type IIb), was more profound than that in muscle containing mixed glycolytic and oxidative fibers (type IIa); no changes occurred in slow-twitch oxidative fibers (type I; Gazzaneo et al., 2011; Columbus et al., 2015). Thus, the differential effect of feeding colostrum on the expression of key components of mTOR signaling and UPS-related genes in the present study may indicate a fiber type-specific response. Such results are also in agreement with the hypothesis that fast-type muscles, such as MLD and MST, are highly responsive to feeding. This likely allows an increased nutrient utilization and consequently higher protein deposition rates in neonates (Gazzaneo et al., 2011), as glycolytic muscles are considered a major component of mass deposition during growth in neonatal pigs (Davis et al., 1996).

In conclusion, upregulation of the key components of mTOR signaling and of MuRF1 at the level of the mRNA indicates a higher rate of protein turnover in muscle of COL calves compared with FOR calves in a muscle type-specific manner. The higher rates of protein turnover may allow AA to be continuously available for protein synthesis and deposition that warrants further investigation. The stimulatory effects observed were likely mediated by the postprandial increase in plasma insulin. Given the fact that proteins may not be proportional to the levels of corresponding mRNA, further studies that include protein expression and activity of selected factors may provide additional clues about the involvement of factors in response to feeding colostrum or formula in neonatal calves.

\section{ACKNOWLEDGMENTS}

The authors thank J. Aschenbrenner from Bergophor Futtermittelfabrik GmbH (Kulmbach, Germany) for donation of the formula and A. Zeyner (University of Rostock, Rostock, Germany) for providing the animal facility. The authors also express their appreciation to K. Karpati (Leibniz Institute for Farm Animal Biology, Dummerstorf, Germany), Y. Zbinden (Veterinary 
Physiology, Vetsuisse Faculty, University of Bern, Bern, Switzerland), and Isabella Israel and Inga Hofs (Institute of Animal Science, Physiology and Hygiene Unit, University of Bonn, Bonn, Germany) for their excellent laboratory assistance. The financial support by Deutsche Forschungsgemeinschaft (Bonn, Germany) is also gratefully acknowledged (HA 4372/5-1).

\section{REFERENCES}

Albert, V., and M. N. Hall. 2015. mTOR signaling in cellular and organismal energetics. Curr. Opin. Cell Biol. 33:55-66.

Baumrucker, C. R., and J. W. Blum. 1994. Effects of dietary recombinant human insulin-like growth factor on concentrations of hormones and growth factors in the blood of newborn calves. J. Endocrinol. 140:15-21.

Blum, J., and H. M. Hammon. 2000. Colostrum effects on the gastrointestinal tract, and on nutritional, endocrine and metabolic parameters in neonatal calves. Livest. Prod. Sci. 66:1151-1159.

Blum, J. W. 2006. Nutritional physiology of neonatal calves. J. Anim. Physiol. Anim. Nutr. (Berl.) 90:1-11.

Bodine, S. C., E. Latres, S. Baumhueter, V. K. Lai, L. Nunez, B. A Clarke, W. T. Poueymirou, F. J. Panaro, E. Na, K. Dharmarajan, Z. Q. Pan, D. M. Valenzuela, T. M. DeChiara, T. N. Stitt, G. D. Yancopoulos, and D. J. Glass. 2001. Identification of ubiquitin ligases required for skeletal muscle atrophy. Science 294:1704-1708.

Burrin, D. G., T. A. Davis, S. Ebner, P. A. Schoknecht, M. L. Fiorotto, and P. J. Reeds. 1997. Colostrum enhances the nutritional stimulation of vital organ protein synthesis in neonatal pigs. J. Nutr. 127:1284-1289.

Burrin, D. G., T. A. Davis, S. Ebner, P. A. Schoknecht, M. L. Fiorotto, P. J. Reeds, and S. McAvoy. 1995. Nutrient-independent and nutrient-dependent factors stimulate protein synthesis in colostrumfed newborn pigs. Pediatr. Res. 37:593-599.

Burrin, D. G., R. J. Shulman, P. J. Reeds, T. A. Davis, and K. R. Gravitt. 1992. Porcine colostrum and milk stimulate visceral organ and skeletal muscle protein synthesis in neonatal piglets. J. Nutr. 122:1205-1213.

Bustin, S. A., V. Benes, J. A. Garson, J. Hellemans, J. Huggett, M. Kubista, R. Mueller, T. Nolan, M. W. Pfaffl, G. L. Shipley, J. Vandesompele, and C. T. Wittwer. 2009. The MIQE guidelinesMinimum information for publication of quantitative real-time PCR experiments. Clin. Chem. 55:611-622.

Centner, T., J. Yano, E. Kimura, A. S. McElhinny, K. Pelin, C. C. Witt, M.-L. Bang, K. Trombitas, H. Granzier, C. C. Gregorio, H. Sorimachi, and S. Labeit. 2001. Identification of muscle specific ring finger proteins as potential regulators of the titin kinase domain. J. Mol. Biol. 306:717-726.

Cohen, S., J. J. Brault, S. P. Gygi, D. J. Glass, D. M. Valenzuela, C. Gartner, E. Latres, and A. L. Goldberg. 2009. During muscle atrophy, thick, but not thin, filament components are degraded by MuRF1-dependent ubiquitylation. J. Cell Biol. 185:1083-1095.

Columbus, D. A., J. Steinhoff-Wagner, A. Suryawan, H. V. Nguyen, A. Hernandez-Garcia, M. L. Fiorotto, and T. A. Davis. 2015. Impact of prolonged leucine supplementation on protein synthesis and lean growth in neonatal pigs. Am. J. Physiol. Endocrinol. Metab. 309:E601-E610.

David, Y., Z. Tamar, A. Admon, and A. Navon. 2010. The E2 ubiquitin-conjugating enzymes direct polyubiquitination to preferred lysines. J. Biol. Chem. 285:8595-8604.

Davis, T. A., D. G. Burrin, M. L. Fiorotto, and H. V. Nguyen. 1996. Protein synthesis in skeletal muscle and jejunum is more responsive to feeding in 7- than in 26-day-old pigs. Am. J. Physiol. 270:E802-E809.

Davis, T. A., M. L. Fiorotto, H. V. Nguyen, and P. J. Reeds. 1989. Protein turnover in skeletal muscle of suckling rats. Am. J. Physiol. 257:R1141-R1146.
Davis, T. A., A. Suryawan, R. A. Orellana, M. L. Fiorotto, and D. G. Burrin. 2010. Amino acids and insulin are regulators of muscle protein synthesis in neonatal pigs. Animal 4:1790-1796.

Dimitriadis, G., P. Mitrou, V. Lambadiari, E. Maratou, and S. A. Raptis. 2011. Insulin effects in muscle and adipose tissue. Diabetes Res. Clin. Pract. 93:S52-S59.

Ferré, P., J. F. Decaux, T. Issad, and J. Girard. 1986. Changes in energy: Metabolism during the suckling and weaning period in the newborn. Reprod. Nutr. Dev. 26:619-631.

Fiorotto, M. L., T. A. Davis, P. J. Reeds, and D. G. Burrin. 2000. Nonnutritive factors in colostrum enhance myofibrillar protein synthesis in the newborn pig. Pediatr. Res. 48:511-517.

Foletta, V. C., L. J. White, A. E. Larsen, B. Léger, and A. P. Russell. 2011. The role and regulation of MAFbx/atrogin-1 and MuRF1 in skeletal muscle atrophy. Pflugers Arch. 461:325-335.

Gazzaneo, M. C., R. A. Orellana, A. Suryawan, A. P. Tuckow, S. R. Kimball, F. A. Wilson, H. V. Nguyen, R. M. Torrazza, M. L. Fiorotto, and T. A. Davis. 2011. Differential regulation of protein synthesis and mTOR signaling in skeletal muscle and visceral tissues of neonatal pigs after a meal. Pediatr. Res. 70:253-260.

Girard, J. 1990. Metabolic adaptations to changes of nutrition at birth. Biol. Neonate 58:3-15.

Gomes, M. D., S. H. Lecker, R. T. Jagoe, A. Navon, and A. L. Goldberg. 2001. Atrogin-1, a muscle-specific F-box protein highly expressed during muscle atrophy. Proc. Natl. Acad. Sci. USA 98:14440-14445.

Grütter, R., and J. W. Blum. 1991. Insulin and glucose in neonata calves after peroral insulin and intravenous glucose administration. Reprod. Nutr. Dev. 31:389-397.

Gunawan, A. M., S. K. Park, J. M. Pleitner, L. Feliciano, A. L. Grant, and D. E. Gerrard. 2007. Contractile protein content reflects myosin heavy-chain isoform gene expression. J. Anim. Sci. 85:12471256.

Hammon, H., and J. W. Blum. 1997. The somatotropic axis in neonatal calves can be modulated by nutrition, growth hormone, and long-R3-IGF-I. Am. J. Physiol. 273:E130-E138.

Hammon, H., and J. W. Blum. 1999. Free amino acids in plasma of neonatal calves are influenced by feeding colostrum for different durations or by feeding only milk replacer. J. Anim. Physiol. Anim. Nutr. (Berl.) 82:193-204.

Hammon, H. M., S. N. Sauter, M. Reist, Y. Zbinden, C. Philipona, C. Morel, and J. W. Blum. 2003. Dexamethasone and colostrum feeding affect hepatic gluconeogenic enzymes differently in neonatal calves. J. Anim. Sci. 81:3095-3106.

Hay, N., and N. Sonenberg. 2004. Upstream and downstream of mTOR. Genes Dev. 18:1926-1945.

Hellemans, J., G. Mortier, A. De Paepe, F. Speleman, and J. Vandesompele. 2007. qBase relative quantification framework and software for management and automated analysis of real-time quantitative PCR data. Genome Biol. 8:R19.

Inoki, K., and K. L. Guan. 2006. Complexity of the TOR signaling network. Trends Cell Biol. 16:206-212.

Kuhla, B., M. Kucia, S. Görs, D. Albrecht, M. Langhammer, S. Kuhla, and C. C. Metges. 2010. Effect of high-protein diet on food intake and liver metabolism during pregnancy, lactation and after weaning in mice. Proteomics 10:2573-2588.

Nandi, D., P. Tahiliani, A. Kumar, and D. Chandu. 2006. The ubiquitin-proteasome system. J. Biosci. 31:137-155.

Ontsouka, E. C., C. Albrecht, and R. M. Bruckmaier. 2016. Growthpromoting effects of colostrum in calves based on interaction with intestinal cell surface receptors and receptor-like transporters. J. Dairy Sci. 99:4111-4123.

Penchev Georgiev, I. 2008. Differences in chemical composition between cow colostrum and milk. Bulg. J. Vet. Med. 11:3-12.

Proud, C. G. 2006. Regulation of protein synthesis by insulin. Biochem. Soc. Trans. 34:213-216.

Rauprich, A. B. E., H. M. Hammon, and J. W. Blum. 2000. Effects of feeding colostrum and a formula with nutrient contents as colostrum on metabolic and endocrine traits in neonatal calves. Biol. Neonate 78:53-64. 
Saremi, B., H. Sauerwein, S. Dänicke, and M. Mielenz. 2012. Technical note: Identification of reference genes for gene expression studies in different bovine tissues focusing on different fat depots. J. Dairy Sci. 95:3131-3138.

Schäff, C. T., D. Rohrbeck, J. Steinhoff-Wagner, E. Kanitz, H. Sauerwein, R. M. Bruckmaier, and H. M. Hammon. 2014. Effects of colostrum versus formula feeding on hepatic glucocorticoid and $\alpha 1$ - and 32 -adrenergic receptors in neonatal calves and their impact on glucose and lipid metabolism. J. Dairy Sci. 97:6344-6357.

Steinhoff-Wagner, J., S. Görs, P. Junghans, R. M. Bruckmaier, E. Kanitz, C. C. Metges, and H. M. Hammon. 2011. Intestinal glucose absorption but not endogenous glucose production differs between colostrum- and formula-fed neonatal calves. J. Nutr. 141:48-55.

Steinhoff-Wagner, J., R. Zitnan, U. Schönhusen, H. Pfannkuche, M. Hudakova, C. C. Metges, and H. M. Hammon. 2014. Diet effects on glucose absorption in the small intestine of neonatal calves: Importance of intestinal mucosal growth, lactase activity, and glucose transporters. J. Dairy Sci. 97:6358-6369.

Thomas, J. D., Y. J. Zhang, Y. H. Wei, J. H. Cho, L. E. Morris, H. Y. Wang, and X. F. Zheng. 2014. mTORC1 activator and a colorectal oncogene. Cancer Cell 26:754-769.

Vacher, P. Y., G. Bestetti, and J. W. Blum. 1995. Insulin-like growth factor I absorption in the jejunum of neonatal calves. Biol. Neonate $68: 354-367$.

Zanker, I. A., H. Hammon, and J. W. Blum. 2000. Plasma amino acid pattern during the first month of life in calves fed the first colostrum at $0-2 \mathrm{~h}$ or at $24-25 \mathrm{~h}$ after birth. J. Vet. Med. A Physiol. Pathol. Clin. Med. 47:107-121. 